\title{
Organisasi Kemiliteran Pada Masa Pengaruh Islam Dan Kolonial Di Jawa
}

\author{
Novida Abbas
}

Keywords: military archaeology, colonial, islam, social, politics

\section{How to Cite:}

Abbas, N. (2007). Organisasi Kemiliteran Pada Masa Pengaruh Islam Dan Kolonial Di Jawa. Berkala Arkeologi, 27(2), 32-39. https://doi.org/10.30883/jba.v27i2.951

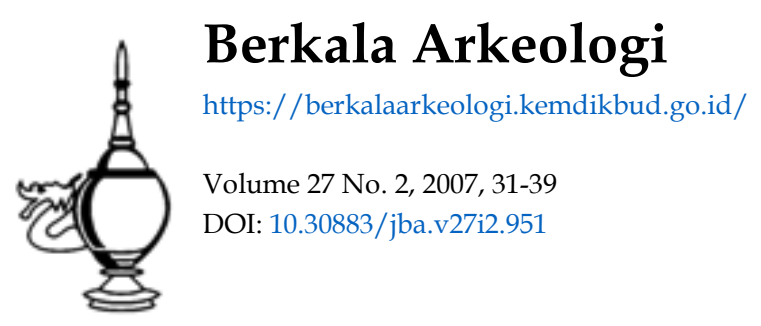




\title{
ORGANISASI KEMILITERAN \\ PADA MASA PENGARUH ISLAM DAN KOLONIAL \\ DI JAWA
}

\author{
Novida Abbas \\ (Balai Arkeologi Yogyakarta)
}

\section{Pendahuluan}

Sejumlah tinggalan arkeologi militer, yang ditemukan di berbagai tempat di Indonesia, baik berupa tinggalan monumental seperti berbagai benteng lokal maupun kolonial dan juga tinggalan non-monumental seperti persenjataan, mencerminkan adanya konstelasi politik, sosial dan ekonomi yang melatari berdirinya tinggalan tersebut. Secara kronologis, meski pun tidak harus linier urutannya, tinggalan arkeologi militer berupa benteng kolonial berawal dari upaya untuk mengamankan kegiatan ekonomi dengan menancapkan tempat-bertumpu (beachhead) di tempat-tempat yang strategis sebelum kemudian berevolusi secara alami menjadi perangkat keras untuk menunjukkan peran politik kolonialnya. Sementara itu (atau sebaliknya), pendirian benteng-benteng lokal atau non-kolonial lebih merupakan sebuah respons untuk mengimbangi perkembangan dan penyebaran benteng-benteng kolonial di masa lalu yang dianggap mengancam kekuasaan raja-raja lokal.

Kajian tentang organisasi kemiliteran, yang terkait erat dengan perkembangan dan persebaran benteng-benteng, pada masa pengaruh Islam dan kolonial di Jawa masih jarang dilakukan. Oleh karenanya, dalam tulisan ini dipaparkan mengenai keberadaan organisasi militer di Jawa pada masa kolonial, yaitu ketika terjadi berbagai pertikaian di antara kerajaan Mataram Islam dengan "penguasa" kolonial Belanda.

\section{Organisasi Kemiliteran Lokal}

Di Jawa pada abad XVI-XVII jumlah prajurit profesional sedikit. Umumnya mereka adalah milik raja/bangsawan/saudagar kaya. Mereka tidak digaji, hanya waktu perang diberi perlengkapan, senjata, beras, dan 
ikan. Salah satu kerajaan besar di Jawa pada masa pengaruh Islam adalah Mataram Islam, yang nantinya akan pecah menjadi dua, yaitu Kesunanan Surakarta dan Kesultanan Yogyakarta. Di masa yang lebih kemudian muncul dua kekuasaan lagi di Surakarta dan Yogyakarta, yaitu Mangkunegaran dan Paku Alaman. Di bawah ini dikemukakan mengenai organisasi militer yang terdapat dalam kerajaan-kerajaan tersebut.

\subsection{Kemiliteran dalam Kerajaan Mataram}

Pada tahun 1588 Mataram menjadi kerajaan dengan Sutawijaya sebagai Sultan yang pertama. Gelarnya telah mencerminkan kedudukannya sebagai pimpinan militer yang sekaligus pimpinan agama, yaitu Senapati Ingalaga Sayidin Panatagama, yang berarti: Panglima Perang dan Ulama Pengatur Kehidupan Beragama.

Sebelum pengaruh Belanda masuk ke lingkungan kraton Mataram, jabatan kemiliteran kerajaan Mataram masih menggunakan sistem tradisional. Pejabat militer memiliki gelar Senapati, Panji, Lurah, dan Bekel Prajurit. Raja memiliki prajurit tetap yang bertugas sebagai penjaga istana. Prajurit tetap tersebut diberi gaji maupun jaminan hidup, dan di antaranya ada yang dipilih menjadi pengawal pribadi raja. Di masa perang, raja mengerahkan rakyatnya untuk maju ke medan perang sebagai milisi. Jabatan mata-mata juga telah terdapat di masa itu, yang dikenal dengan istilah telik sandi.

Setelah Kerajaan Mataram terbagi dua menjadi Surakarta dan Yogyakarta, organisasi kemiliteran dalam kerajaan-kerajaan tersebut telah mengalami kemajuan dan lebih teratur.

\subsubsection{Kemiliteran di Kesultanan Yogyakarta}

Organisasi militer di Kraton Yogyakarta dibentuk pada masa pemerintahan Sultan Hamengku Buwana I sekitar thn 1755, dan terdiri atas pasukanpasukan infantri dan kavaleri yang sudah menggunakan senjata api berupa bedil dan meriam. Pasukan Yogyakarta terkenal cukup kuat, yang terbukti ketika Sultan Hamengku. Buwana II mengadakan perlawanan bersenjata menghadapi serbuan pasukan Inggris yang dipimpin oleh Jenderal Gillespie pada bulan Juni 1812 . 
Akibat perlawanan tersebut, pada masa pemerintahan Sultan Hamengku Buwana III Inggris membubarkan angkatan perang Kesultanan Yogyakarta. Dalam perjanjian 2 Oktober 1813 yang ditandatangani Sultan Hamengku Buwana III dan Raffles, tertulis bhw Kesultanan Yogyakarta tidak boleh memiliki angkatan bersenjata yang kuat. Di bawah pengawasan Inggris, kraton hanya boleh memiliki kesatuan-kesatuan bersenjata dengan pembatasan jumlah personil. Sejak itu fungsi kesatuan-kesatuan bersenjata sebatas sebagai pengawal sultan dan penjaga kraton.

Ketika Pemerintahan Kolonial Belanda kembali berkuasa, pasukan-pasukan bersenjata yang sudah lemah tersebut makin dikurangi sehingga tidak mempunyai arti secara militer. Menurut catatan, semasa pemerintahan Sultan Hamengku Buwono VII - Hamengku Buwono VIII (1877-1939) terdapat 13 kesatuan prajurit atau bergada, yaitu Kesatuan Sumoatmojo, Ketanggung; Patangpuluh, Wirobrojo, Jogokaryo, Nyutro, Dhaeng, Jager, Prawirotomo, Mantrijero, Langenastro, Surokarso, dan Bugis. Selanjutnya pada masa pendudukan Jepang semua kesatuan bersenjata di Kraton Yogyakarta dibubarkan oleh Jepang. Baru pada sekitar tahun 1970-an sebagian kesatuan prajurit keraton dihidupkan kembali dengan beberapa modifikasi, meskipun hanya untuk kepentingan upacara saja dan tidak lagi ditujukan untuk kegiatan kemiliteran murni. Saat ini kesatuan-kesatuan prajurit Kraton Yogyakarta masih dapat disaksikan 3 kali dalam setahun, yaitu pada upacara Garebeg Maulud, Garebeg Besar, dan Garebeg Syawal di alun-alun utara Kraton Yogyakarta.

\subsubsection{Kemiliteran di Kesunanan Surakarta}

Sementara di Kesunanan Surakarta kekuasaan Sunan di bidang politik, yang mencakup pula kemiliteran, dilimpahkan kepada patih, yang strukturnya disebut Reh Kepatihan atau Reh Kepradatan. Patih dibantu oleh 8 Bupati Nayaka, yang terdiri dari 4 Bupati Lebet dan 4 Bupati Jawi. Pengawas bidang keprajuritan dan pengatur perlengkapan perang berada di bawah urusan 4 Bupati Lebet, yaitu yang disebut Keparak Kiwa, Keparak Tengen, Gedong Kiwa, dan Gedong Tengen. Di Surakarta selain prajurit reguler terdapat pula sekelompok abdi dalem yang tugas pokoknya adalah mengurus segala keperluan ibadah dan upacara keagamaan tetapi juga bertugas sebagai pengawal Sunan, yaitu abdi dalem Suranata. Abdi dalem 
Suranata ini pembentukannya sudah ada sejak zaman Kerajaan Demak, yaitu sebagai kelompok ulama bersenjata yang bertugas mengawal para sultan Demak, sekaligus mengurus hal-hal yang bersifat keagamaan. Di Kesunanan Surakarta abdi dalem Suranata merupakan kelompok pegawai kraton yang setengah militer dan setengah religius yang merupakan bagian dari prajurit jero (prajurit internal kraton). Meskipun setengah militer, namun di dalam struktur pemerintahan kraton, abdi dalem Suranata bersamasama dengan pengulu, khotib, ulama daerah, naib, muazzin, dan merbot masuk di dalam Reh Kapangulon. Reh Kapangulon adalah struktur yang menjalankan kekuasaan raja dalam bidang keagamaan.

Pada abad XVIII-XIX kraton Surakarta maupun Yogyakarta selain memiliki kesatuan bersenjata juga memiliki kesatuan polisi untuk menjaga kemanan dan ketertiban umum, yaitu yang disebut abdi dalem Gunung. Setelah pengaruh Belanda masuk, pangkat dalam kemiliteran Belanda digunakan juga, seperti kolonel, letnan kolonel, mayor, kapten, dan letnan.

\subsubsection{Kemiliteran di Kadipaten Pakualaman}

Kadipaten Pakualaman juga memiliki kesatuan bersenjata, yaitu kesatuan (bergada) Lombok Abang dan bergada Plangkir. Bergada Lombok Abang adalah pasukan pengawal kehormatan jika Paku Alam menghadiri acaraacara resmi, misalnya di Gubernuran (sekarang Gedung Agung di depan Benteng Vredeburg). Bergada Lombok Abang berasal dari kelompok abdi dalem Gladak (dulu merupakan abdi dalem yang bertugas sebagai pengiring dalam upacara sripahllelayu jika ada bangsawan yang meninggal). Kemudian mereka dialihfungsikan menjadi Bergada Lombok Abang yang bermarkas di Kadipaten Pakualaman. Sementara itu bergada Plangkir adalah pasukan berkuda yang sekaligus juga merupakan pasukan infantri, dan berfungsi untuk pertahanan. Dahulu terkenal dengan sebutan "Legiun Pakualaman". Pimpinan bergada sekarang disebut Pandega. Para. prajurit yang terdaftar sebagai abdi dalem tersebut diberi pangkat Jajar, Bekel, Lurah, dan Wedono. Pada masa kini kesatuan prajurit Kadipaten Pakualaman hanya digunakan dalam upacara Garebeg Idul Fitri, Garebeg Besar, dan Garebeg Maulud. 


\subsubsection{Kemiliteran di Kadipaten Mangkunegaran}

Di Mangkunegaran, kesatuan prajuritnya dikenal dengan sebutan "Legiun Mangkunegaran", yang awalnya terdiri dari prajurit-prajurit yang berjuang dengan R.M. Said. Kesatuan yang berjuang membantu R.M. Said tersebut terdiri atas pasukan berkuda (kavaleri) maupun pasukan infantri dan artileri. Terdapat 12 kesatuan di masa itu, yang terdiri atas kesatuan Ladrang, Mangungkung Estri, Jayengsastra, Bijigan, Kapilih, Tamrarudita, Margarudita, Tanusastra Nampil, Mijen, Nyutrayu, Gulanggula, dan Sarageni. Setelah Kadipaten. Mangkunegaran terbentuk, kesatuan-kesatuan itu ditambah lagi dengan Trunakroda, Trunayudaka, Minakan, Tambakbana, Tambakbrata, Dasawani, Dasarambat, Prangtandang, Tirtasana, Gunasemita, dan Gunatalikrama, yang seluruhnya merupakan pasukan infantri. Di antara kesatuan-kesatuan tersebut, kesatuan Mangungkung Estri adalah kesatuan kavaleri yang anggotanya kaum wanita.

Jumlah prajurit dalam 1 kesatuan adalah 44, yang kalau kedua angkanya dijumlahkan berarti 8 , yaitu daur dalam perhitungan waktu yang mengandung makna magis (tumbuk). Masing-masing kesatuan tersebut memelihara kerbau, yang di masa damai digunakan untuk mengolah sawah, sedangkan di masa perang kerbau-kerbau itu digunakan sebagai pengangkut perbekalan maupun persenjataan. Kesatuan-kesatuan itu tidak memiliki seragam dan besaran gajinya ditentukan berdasarkan tugas dan jenis senjata yang digunakan. Pasukan berkuda mendapat gaji yang lebih besar dari pada pasukan darat.

Nama "Legiun Mangkunegaran" mulai digunakan pada masa Mangkunegara II (1808). Pada saat itu Mangkunegara II menjadi komandan legiun dan berpangkat kolonel, sehingga sering disebut Kolonel Komandan.

\section{Organisasi Kemiliteran Belanda}

Angkatan perang Belanda di abad XVII-XIX mempunyai sifat mobile, dan terdiri atas:

- Pasukan-pasukan infantri, kavaleri, artileri.

- Korps-korps khusus seperti zeni, kesehatan, dan sapper. 


\section{- Angkatan laut.}

- Pasukan Jayangsekar, yang dibentuk Belanda di daerah-daerah (terutama di Jawa); dan mempunyai tugas kepolisian untuk menjaga keamanan daerah setempat, tetapi juga sering ditugaskan berperang di daerah sendiri/di daerah lain.

Selain itu juga terdapat tenaga kasar untuk mengangkut perlengkapan senjata, bahan pangan, menarik meriam, serta mengangkut serdaduserdadu yang luka dalam peperangan. Belanda juga biasanya memakai pribumi sebagai penunjuk jalan. Di masa-masa itu pemusatan kekuatan militer disesuaikan dengan situasi daerah. Jika terjadi konflik di suatu tempat, maka pemusatan militer akan dipindahkan ke lokasi itu.

Kekuatan darat Belanda di masa itu dikepalai oleh seorang Brigadir yang membawahi 2 orang letnan kolonel, 1 berkedudukan di Batavia dan 1 lagi berkedudukan di Srilanka. Masing-masing letnan kolonel membawahi 3 orang mayor. Di masa itu apa yang dinamakan pasukan Belanda umumnya terdiri dari serdadu-serdadu berbagai bangsa, dan bukan hanya bangsa Belanda saja. Sebagai contoh di Batavia pada abad XVII pasukan Belanda yang bertanggung jawab atas pertahanan Batavia terdiri atas 240 orang pasukan bantuan Prancis; 600 orang serdadu Belanda; 3 batalyon pasukan nasional yang terdiri dari 200 perwira, tamtama, dan pasukan infantri bangsa Eropa, serta 2200 pasukan Madura; 1 batalyon bintara infantri, terdiri dari 400 orang Madura, 600 orang Madura yang tergabung dalam pasukan artileri, 100 orang Madura yang tergabung dalam 1 kompi artileri ringan, dan 200 orang Eropa yang tergabung dalam pasukan kavaleri. Juga terdapat 1 korps insinyur militer yang terdiri dari orang Prancis, Belanda, Jerman. Komandan seluruh pasukan tersebut adalah seorang Brigadir berkebangsaan Swiss, dan wakilnya adalah seorang Prancis.

Di abad XIX pasukan Belanda mengalami peningkatan dalam segi jumlah. Sebagai contoh di tahun 1816 kekuatan militer Belanda terdiri atas 3000 serdadu Eropa dan 3000 serdadu pribumi. Pada tahun 1825 kekuatan itu diperbesar menjadi 6148 serdadu Eropa, 5734 serdadu pribumi, dan 639 perwira Eropa. Selain itu Belanda juga minta bantuan pada penguasapenguasa lokal, dan hal ini menimbulkan kebencian antar suku. Contohnya 
sewaktu Perang Diponegoro, Belanda minta bantuan dari Sultan Madura 3500-4000 prajurit bersenjata tombak, juga dari daerah-daerah lainnya, misalnya pada tahun 1828 mendapat 1280 serdadu dari Manado, 700 dari Buton, dan 285 dari Tidore. Ketika Belanda menghadapi perlawanan Pattimura di Maluku Selatan pada tahun 1817, Belanda mendapat bantuan 1500 serdadu dari Ternate dan Tidore.

\section{Penutup}

Masih banyak hal-hal yang dapat diungkapkan dari keberadaan tinggalan arkeologi militer di Indonesia. Berbagai aspek kehidupan di masa lalu dapat diketahui dari tinggalan-tinggalan tersebut, tidak hanya aspek militernya semata, melainkan juga aspek keseharian di baliknya. Studi arkeologisejarah diperlukan untuk dapat memberi "nyawa" bagi tinggalan-tinggalan fisik yang ditemukan, sehingga gambaran tentang kehidupan militer di masa lalu dapat lebih banyak diungkapkan. Dengan demikian akan diperoleh pengetahuan yang lebih komprehensif tentang pertumbuhan dan perkembangan kehidupan militer di masa lalu, baik yang terdapat di pihak lokal maupun di pihak kolonial. 


\section{KEPUSTAKAAN}

Catriantoro, DedykAgung. 2000. Abdi Dalem Juru Suranata: Tugas dan Peranannya di Keraton Kasunanan Surakarta. Surakarta. Skripsi pada Jurusan Sejarah Fak. Sastra UNS.

longh, D. de. 1950. Het Krijgswezen onder de Oostindische Compagnie. 's-Gravenhage. N.V. Uitgeverij W.P. van Stockum en Zoon.

Schrieke, B.J.O. 1955-1957. Indonesian Sociological Studies. Part I \& II. The Hague. W. Van Hoeve.

Thorn, William. 2004 (Reprinted). The Conquest of Java. Singapore. Periplus Editions (HK) Ltd.

uww.nationaalarchive.nl.

wuw.tembi.org. 